\title{
Multiple Skin Neoplasms at One Site (MUSK IN A NEST): A Comprehensive Review of Basal Cell Carcinoma and Benign or Malignant "Collision" Tumors at the Same Cutaneous Location
}

This article was published in the following Dove Press journal:

Clinical, Cosmetic and Investigational Dermatology

\author{
Philip R Cohen' \\ Antoanella Calame (iD ${ }^{2}$ \\ 'San Diego Family Dermatology, National \\ City, CA, USA; ${ }^{2}$ Compass \\ Dermatopathology, San Diego, CA, USA
}

\begin{abstract}
Multiple skin neoplasms at one site (MUSK IN A NEST), initially referred to as a collision tumor, describes the occurrence of two or more benign or malignant neoplasms that are adjacent or intermingled at the same cutaneous site. A mononeoplastic cutaneous tumor refers to a single tumor at any cutaneous site. Two, three, four, five, and six tumors at the same site are described as dineoplastic, trineoplastic, tetraneoplastic, pentaneoplastic, and hexaneoplastic cutaneous tumors, respectively; the prefixes are based on the numerical multiplier used by the International Union of Pure and Applied Chemistry (IUPAC). MUSK IN A NEST can be classified based upon their mechanism of pathogenesis-either being composed of mixed clones of cells (clonalium, which has three subtypes: collision, colonization, and combination) or the same clone of cells that has undergone clonal evolution (clonalidem, which has one subtype: biphenotypic). Basal cell carcinoma (BCC)-associated MUSK IN A NEST can be observed with either benign tumors, malignant tumors, or both. Nevi and seborrheic keratoses are the most common benign tumors associated with $\mathrm{BCC}$; melanoma in situ and invasive melanoma are the most commonly reported malignant tumors associated with BCC. The definitive etiology of BCC-associated MUSK IN A NEST remains to be establishedwhether the development of the $\mathrm{BCC}$ at that site occurs as a direct or indirect consequence of the coexisting neoplasm or whether the occurrence of the BCC and the other neoplasm is merely the result of a coincidental juxtaposition of the tumors.
\end{abstract}

Keywords: basal, carcinoma, cell, collision, neoplasm, tumor

\section{Introduction}

The presence of two neoplasms either adjacent to each other or intermingled at the same cutaneous site was originally described as a collision tumor. Several investigators have attempted to further define and better clarify this unique occurrence. Indeed, we have chosen to refer to this unique tumor using a descriptive terminology: multiple skin neoplasms at one site (MUSK IN A NEST).

MUSK IN A NEST can include benign and benign neoplasms, benign and malignant neoplasms, or malignant and malignant neoplasms. Basal cell carcinoma (BCC)-a malignant tumor of the skin-can occur at the same cutaneous location as benign tumors (Table 1). ${ }^{1-48} \mathrm{BCC}$ also occurs at the same site with other malignant tumors (Table 2). ${ }^{12,19,36,49-75}$
Correspondence: Philip R Cohen

Email mitehead@gmail.com 
Table I MUSK IN A NEST: Basal Cell Carcinoma and Benign Tumors

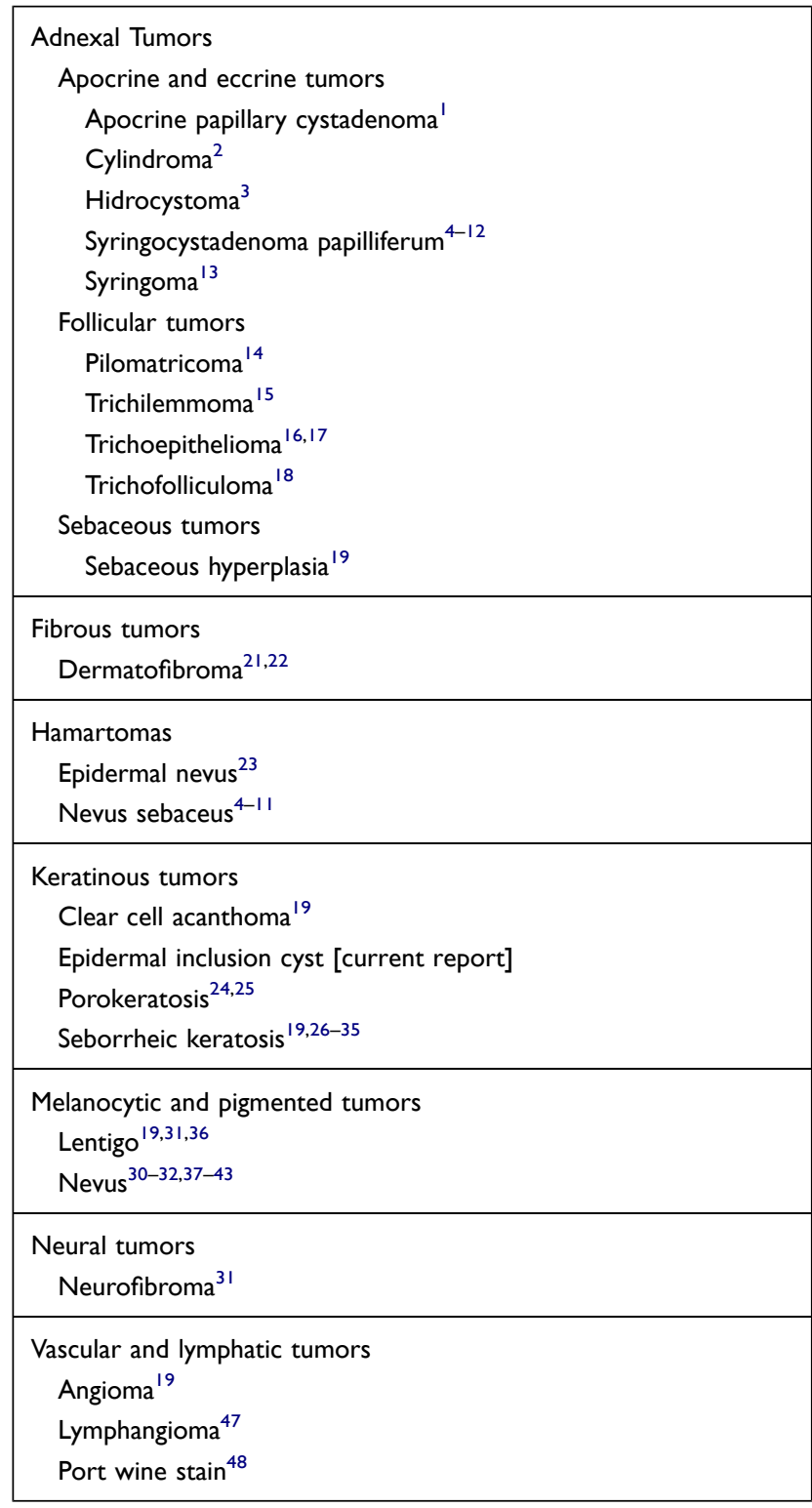

Abbreviation: MUSK IN A NEST, multiple skin neoplasms at one site.

\section{Discussion}

\section{Nomenclature}

There is no inclusive term to categorize the various pathologic variants that may be observed when two tumors are present at the same anatomic location. Therefore, we introduce a descriptive terminology for this occurrence: multiple skin neoplasms at one site. To facilitate the new term, we have also created a simple acronym: MUSK IN A NEST.

The acronym is composed of letters from the descriptive terminology. "MU" is the first two letters of "multiple". "SK" is the first two letters of "skin". "IN" includes the third letter from "skin" and the first letter from "neoplasms". " $A$ " is the
Table 2 MUSK IN A NEST: Basal Cell Carcinoma and Malignant Tumors

\begin{tabular}{l} 
Actinic keratosis $^{19,36}$ \\
Angiosarcoma $^{49}$ \\
Atypical fibroxanthoma $^{50-52}$ \\
Chronic lymphocytic leukemia $^{53}$ \\
Keratoacanthoma $^{19,54-56}$ \\
Leiomyosarcoma $^{57}$ \\
Melanoma $^{58-67}$ \\
Merkel cell carcinoma $^{68}$ \\
Myoepithelial carcinoma $^{69,70}$ \\
Osteosarcoma \\
Sebaceous carcinoma \\
Squamous cell carcinoma $^{73-75}$ \\
Verrucous carcinoma $^{12}$ \\
\hline
\end{tabular}

Abbreviation: MUSK IN A NEST, multiple skin neoplasms at one site.

first letter of "at". "NEST" includes the second and third letters of "one" and the first and third letters of "site".

To assist in remembering the acronym, it is helpful to know that "musk" refers to the musk duck which is native in Australia. During mating season, the duck emanates a peculiar musky odor; thus the derivation of its name. The male duck neither builds the nest nor raises the young. Hence, these responsibilities are those of the female duck. $^{76}$

"Musk" also refers to the musk lorikeet. The bird is native in Australia. It is mainly green with a red forehead, a blue crown, and a yellow band on its wing. The female lorikeet incubates the eggs in its nest that is typically found in a high hollow tree limb. ${ }^{77}$

Terminology for the number of tumors at a single site is summarized in Table $3 .^{78}$ Most BCCassociated MUSK IN A NEST are dineoplastic cutaneous tumors. However, BCC associated with two or more additional skin neoplasms have been observed (Table 4). ${ }^{4-12,24,32,34,43,45,46,79-81}$

\section{Epidemiology}

In a retrospective study from the dermatopathology laboratory of a single institution, a total of 40,000 cutaneous biopsy specimens were evaluated. Only 69 specimens $(0.17 \%)$ had two or more contiguous neoplasms that were within a millimeter of each other. The investigators concluded that most of the cutaneous collision tumors that they observed represented a coincidental juxtaposition of the neoplasms. ${ }^{31}$

Another retrospective study involved researchers from 21 pigmented lesion clinics in nine countries. 
Table 3 Terminology for Multiple Skin Neoplasms at One Site (MUSK IN A NEST) $^{\mathrm{a}, \mathrm{b}}$

\begin{tabular}{|l|l|}
\hline Tumor Terminology & $\begin{array}{l}\text { Number of Neoplasms at } \\
\text { the Same Cutaneous } \\
\text { Location }\end{array}$ \\
\hline Dineoplastic cutaneous tumor & Two skin neoplasms \\
Trineoplastic cutaneous tumor & Three skin neoplasms \\
Tetraneoplastic cutaneous tumor & Four skin neoplasms \\
Pentaneoplastic cutaneous tumor & Five skin neoplasms \\
Hexaneoplastic cutaneous tumor & Six skin neoplasms \\
Heptaneoplastic cutaneous tumor & Seven skin neoplasms \\
Octaneoplastic cutaneous tumor & Eight skin neoplasms \\
Nonaneoplastic cutaneous tumor & Nine skin neoplasms \\
Decaneoplastic cutaneous tumor & Ten skin neoplasms \\
\hline
\end{tabular}

Notes: ${ }^{a} \mathrm{~A}$ single neoplasm at any cutaneous site would be referred to as a mononeoplastic cutaneous tumor. ${ }^{\mathrm{b}}$ To the best of our knowledge, we are only aware of mononeoplastic, dineoplastic, trineoplastic, tetraneoplastic, pentaneoplastic and hexaneoplastic cutaneous tumors involving a basal cell carcinoma. 'The prefixes used for the neoplasm terminology are those of the numerical multiplier (or multiplying affix) in the International Union of Pure and Applied Chemistry (IUPAC) nomenclature. ${ }^{78}$

Abbreviation: MUSK IN A NEST, multiple skin neoplasms at one site.

Dermoscopic images of histopathologically diagnosed collision skin lesions were being evaluated. The multicenter study only identified 77 collision skin lesions during a 6-month period of evaluation. ${ }^{19}$

The incidence of BCC-associated MUSK IN A NEST, in studies of collision tumors, varied from 39\% (27 of 69 tumors $^{31}$ to $45 \%$ (35 of 77 tumors) ${ }^{19}$ to $54 \%$ (13 of 24 tumors) ${ }^{32}$ overall, the incidence was $44 \%$ (74 of 170 tumors). Other investigators retrospectively evaluated 412 BCCs to determine the incidence of collision tumors. They observed either a solar lentigo (six tumors), basal layer hyperpigmentation (three tumors), a compound nevus (two tumors) or an actinic keratosis (one tumor) in $12(3 \%)$ of the $\mathrm{BCC}^{36}$

\section{Classification}

MUSK IN A NEST was originally referred to as a collision tumor. ${ }^{19,31,32,36}$ However, additional observations of this phenomenon-suggested by the pathologic pattern of the coexisting neoplasms (and particularly with regards to BCC and melanoma)-prompted investigators to define four variations of coexisting neoplasms. These included (ranging from the two neoplasms being the least admixed to the most admixed) collision, colonization, combination, and biphenotypic tumors. ${ }^{64,82}$

A collision tumor refers to two independent cutaneous neoplasms that are contiguously next to each other at the same anatomic site. Colonization refers to a tumor in which one distinct neoplasm (such as melanoma in situ) has infiltrated
Table 4 Multiple Skin Neoplasms at One Site (MUSK IN A NEST)-Basal Cell Carcinoma and Two or More Additional Cutaneous Neoplasms

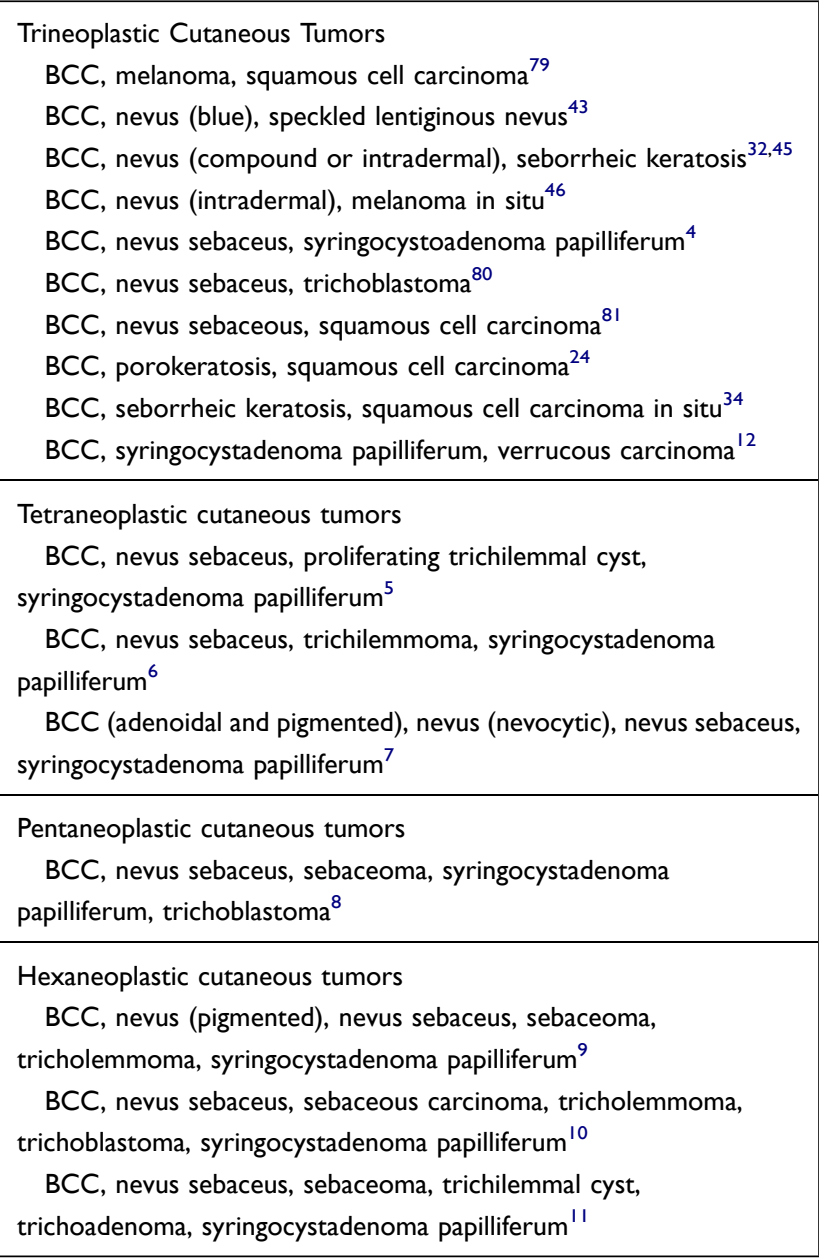

Abbreviations: BCC, basal cell carcinoma; MUSK IN A NEST, multiple skin neoplasms at one site.

a second distinct neoplasm (such as a BCC); however, the infiltrating neoplasm is confined only to the second neoplasm without any invasion into the adjacent dermis. A combination tumor refers to a tumor in which the two distinct neoplasms are intimately intermingled. A biphenotypic tumor refers to a tumor that initially originates from the same stem cell or single clone of cells and subsequently differentiates into two neoplasms that are phenotypically distinctive; hence, neoplasms of the tumors have common genetic, ultrastructural, and immunohistochemical features. ${ }^{64,82}$

After completing our assessment of the literature, we propose that a classification of MUSK IN A NEST that is based upon the postulated mechanism of pathogenesis will enable a better understanding and categorization of these tumors. Hence, we have created primary categories based on whether there are mixed clones (clonalium) or clonal 
evolution (clonalidem). The terms are derived from using the "clonal" prefix followed by the Latin term "alium" for different or "idem" for same (Table 5).

Clonalium refers to tumors with two or more different clones. This category includes tumors characterized by either collision, colonization, or combination of the neoplasms. In contrast, clonalidem refers to tumors consisting of a single stem cell or a single clone of cells that has differentiated into two different tumors; this corresponds to biphenotypic neoplasms (Table 5).

\section{Pathogenesis}

Four theories for the etiology of MUSK IN A NEST have been postulated. The first theory is the occurrence of the two neoplasms at the same cutaneous location may merely be due to chance alone. ${ }^{31}$ The second theory is the development of the second tumor occurred because epithelial or stromal changes were induced by the first tumor. ${ }^{31}$ A similar hypothesis proposed for the development of melanocytic tumors at the same site as a basal cell carcinoma-and described as the interaction theory-suggests that the unrestrained growth of the neoplastic cells and melanocytic tumor result from BCCinduced increased growth factors and cytokines in that area of skin. ${ }^{64}$

The third theory is that of a field cancerization phenomenon. In an anatomic skin location where the two neoplasms typically develop, exposure to ultraviolet radiation or

Table 5 Classification of Multiple Skin Neoplasms at One Site (MUSK IN A NEST)

\begin{tabular}{|l|} 
Clonalium $^{\mathrm{a}}$ \\
Collision $^{\mathrm{b}}$ \\
Colonization $^{\mathrm{c}}$ \\
Combination $^{\mathrm{d}}$ \\
\hline $\begin{array}{c}\text { Clonalidem }^{\mathrm{e}} \\
\text { Biphenotypic }^{\mathrm{f}}\end{array}$ \\
\hline
\end{tabular}

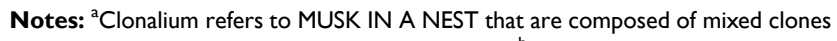
of cells; the suffix "alium" is Latin for "different". 'Collision tumor refers to two histologically distinct neoplasms that are in close proximity (adjacent) to each other at the same cutaneous location. These have also been referred to as contiguous tumors. 'Colonization of a tumor refers to one independent neoplasm that has infiltrated, yet is confined, to a second independent neoplasm; melanoma in situ that only occupies the dermal nests of basal cell carcinoma without any invasion into the adjacent dermis is an example of colonization of the basal cell carcinoma by the melanoma in situ. ${ }^{\mathrm{d} C o m b i n a t i o n}$ tumor refers to intimately intertwined populations of two distinct neoplasms. These have also been referred to as intermingled tumors. ${ }^{\text {e}}$ Clonalidem refers to MUSK IN A NEST that are originate from one clone of cells with subsequent clonal evolution of that single clone; the suffix "idem" is Latin for "same". 'Biphenotypic tumor refer to a neoplasm that derives from a single clone of cells or the same stem cell and then differentiate divergently into two phenotypically different tumors; however, both tumors have the common genetic, ultrastructural and immunohistochemical features.

Abbreviation: MUSK IN A NEST, multiple skin neoplasms at one site. another environmental carcinogen primed the cutaneous site and thereby enhanced the chance for both to concurrently appear at the same cutaneous location. ${ }^{58}$ Finally, the fourth theory, stem cell cancerization, is that a common stem or progenitor cell or a single clone undergoes dual differentiation and a biphasic neoplasm develops ${ }^{79}$ examples of biphenotypic tumors-some of which are controversial-include a malignant neoplasm with features of both squamous cell carcinoma and malignant melanoma, ${ }^{83}$ and a BCC and a melanoma (basomelanocytic tumor). ${ }^{84}$

\section{BCC-Associated MUSK IN A NEST and Benign Tumors Adnexal Tumors}

BCC-associated MUSK IN A NEST have been observed with adnexal tumors. These including benign apocrine and eccrine neoplasms. Individual reports describe collision tumors consisting of basal cell carcinoma with either an apocrine papillary cystadenoma, ${ }^{1}$ a cylindroma, ${ }^{2}$ or a hidrocystoma. ${ }^{3}$ A case series of three women with clinically unapparent syringoma that were found incidentally during Mohs micrographic excision of BCC have also been reported; the subclinical syringoma were either adjacent (2 patients with clonalium collision tumors) or admixed (1 patient with a clonalium combination tumor). ${ }^{13}$

Several patients with BCC-associated syringocystadenoma papilliferum have been described. In addition to the benign apocrine neoplasm, most of these patients MUSK IN A NEST developed in a nevus sebaceus; in addition, many of the individuals had additional neoplasm present. ${ }^{4-11}$ One patient, a 65-year-old man with a growing 6 centimeter exophytic mass on his left occipital scalp of 5-years duration, also had a concurrent verrucous carcinoma. ${ }^{12}$

$\mathrm{BCC}$ has also been associated with benign follicular and sebaceous adnexal tumors. MUSK IN A NEST consisting of a follicular tumor and BCC include not only trichilemmoma (on the left cheek of a 75-year-old farmer), ${ }^{15}$ and trichofolliculoma (on the right nasolabial sulcus of a 52-year-old woman), ${ }^{18}$ but also trichoepithelioma; the latter has been observed in individuals who have either a solitary adnexal tumor ${ }^{16}$ or multiple facial neoplasms. ${ }^{17}$ BCC-associated with a pilomatricoma was described in a 29 -year-old man with a tumor that was located on the medial aspects of both the upper and lower right eyelids, the right medial canthus and extended onto the right side of the upper half of his nose; it grew to 3-centimeters and ulcerated over a period of 8 months. ${ }^{14}$ In addition, sebaceous hyperplasia and BCC have been observed in two individuals. ${ }^{19}$ 


\section{Fibrous Tumors}

The first well-documented report of a BCC overlying a dermatofibroma was described on the outer side of the left upper arm of a 65-year-old woman in 1964; she recalled a lesion being present at the site for many years which had slowly enlarged and occasionally developed a crust during the prior year. ${ }^{20}$ However, not only $\mathrm{BCC}$ but also BCC-like changes have been observed extending from the epithelium overlying a dermatofibroma. ${ }^{21}$ Indeed, one group of investigators found only three specimens demonstrating BCC and 19 specimens showing BCC-like changes when they reviewed specimens received by the Armed Forces Institute of Pathology during a 22-year period. ${ }^{21}$ It has been proposed that dermal factors and the resultant mesodermal alteration that occur secondary to the dermatofibroma have a critical role in the histogenesis of the development of the BCC in the overlying epithelium. ${ }^{22}$

\section{Hamartomas}

Hamartomas of the skin include epidermal nevus and nevus sebaceus. Epidermal nevus is a benign congenital lesion that often follows Blaschko's lines and is typically present at birth or within the first year of life. At least five patients with MUSK IN A NEST consisting of BCC associated an epidermal nevus have been described. ${ }^{23}$

Nevus sebaceous is a benign hamartomatous tumor that appears at birth or in early childhood as a flat yellowish plaque that becomes thickened and verrucous either during or following adolescence. It can be associated with the development of one or more benign or malignant neoplasms. ${ }^{85}$ However, several nevus sebaceous contain not only BCC but also syringocystadenoma papilliferum and/or other tumors. ${ }^{4-11}$

\section{Keratinous Tumors}

BCC has been associated with several keratinous tumors. These include clear cell acanthoma, epidermal inclusion cyst, porokeratosis, and seborrheic keratosis. The clear cell acanthoma was observed in a dermoscopy study of collision skin lesions. ${ }^{19}$

We observed a woman with a 78-year-old woman with a MUSK IN A NEST comprised a combination clonalium tumor consisting of a nodular basal cell carcinoma and an epidermal inclusion cyst (Figures 1-3). Her lesion has been present for several years; however, it began to appear darker and increase in size. She also had a previous history of a pigmented nodular basal cell carcinoma associated with a seborrheic keratosis on her left breast that morphologically mimicked a melanoma. ${ }^{26}$
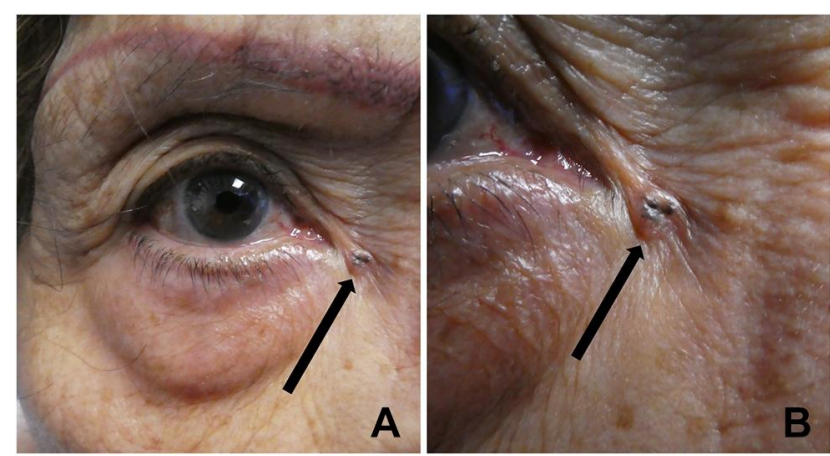

Figure I Clinical presentation of multiple skin neoplasms at one site (MUSK IN A NEST) consisting of a nodular basal cell carcinoma and an epidermal inclusion cyst on the skin near the right medial canthus. Distant (A) and closer (B) views of an asymptomatic flesh-colored umbilicated $5 \times 5$ millimeter nodule with central black pigment (black arrow) of less than 6 months duration located near the right medial canthus of a 78-year-old woman. The clinical differential diagnosis included an epidermoid cyst and a pigmented basal cell carcinoma. A shave biopsy of the lesion was performed.

Malignancy may develop in lesions of porokeratosis; the tumor is usually either a squamous cell carcinoma or squamous cell carcinoma in situ. BCC-associated with porokeratosis is rare; it was initially described by Bazex and Dupre in 1968. Subsequently, Sarkany reported of a 55-year-old man with a right thigh tumor whose biopsy showed a combined clonalium tumor of porokeratosis and BCC in 1973; the excision specimen not only confirmed the presence of porokeratosis and BCC but also contained squamous cell carcinoma. Thereafter, a few additional observations of BCC and porokeratosis as MUSK IN A NEST have been published. ${ }^{24,25}$

The first report of BCC-associated seborrheic keratosis was presented by Dr. Sibley at a meeting of the Royal Society of Medicine on December 17, 1931. Skin biopsies had been performed on a 65-year-old man with several "seborrheic verrucae and multiple basal-celled epitheliomata". Additional review of one of the biopsy specimens demonstrated that a BCC took its origin from the seborrheic keratosis. ${ }^{27-29}$ Subsequently, investigators have postulated that the two tumors were either derived from pluripotential cells in the basal layer of the epidermis or the hair follicle epithelium or that the presence of both tumors was merely a coincidence of two common lesions being juxtaposed. ${ }^{30}$

Several retrospective studies of MUSK IN A NEST involving seborrheic keratoses and $\mathrm{BCC}$ have been conducted. ${ }^{19,29,31-35}$ The incidence of BCC-associated seborrheic keratosis ranges from $0.02 \%$ ( 8 of 40,000 specimens $)^{31}$ to less than $0.14 \%$ (14 of greater than 10,000 specimens) ${ }^{29}$ the median was $0.05 \%$ (43 of 85,000 specimen). ${ }^{35}$ Studies specifically evaluating collision tumors observed the frequency of 


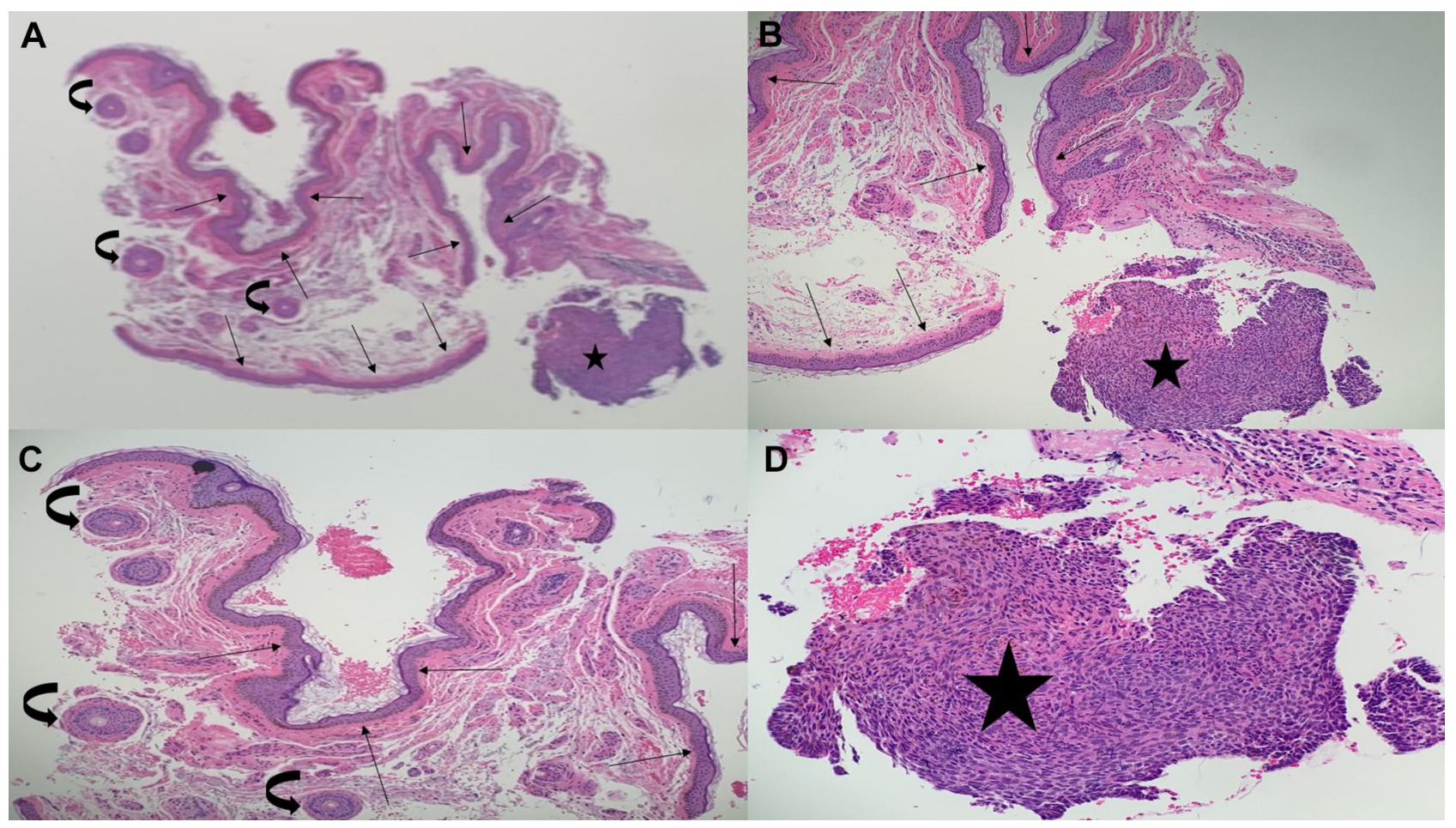

Figure 2 Microscopic examination of the nodule on the skin near the right medial canthus of a 78-year-old woman showed multiple skin neoplasms at one site (MUSK IN A NEST) consisting of a nodular basal cell carcinoma and an epidermoid cyst. Low magnification view (A) and higher magnification views (B-D) of the hematoxylin and eosin stained tissue specimen are shown. The orientation of the specimen during processing resulted in horizontal sectioning of the tissue. Only dermal tissue without the overlying epidermis, is observed; therefore, all of the hair follicles (curved black arrows) are cut in cross-section (transverse section) instead of longitudinal section. There is a nodular aggregate of basaloid tumor cells (black star) adjacent to several portion of a cyst that contains keratin (straight black arrows). Pigment is present in the tumor aggregate; in addition, there is hyperpigmentation of the cyst wall epithelium (hematoxylin and eosin: A, x2; B, x4; C, x 4; D, x 10).

BCC-seborrheic keratosis MUSK IN A NEST to range from $12 \%$ ( 8 of 69 tumors) ${ }^{31}$ to $33 \%$ ( 8 of 24 tumors) $)^{32}$ the median was $23 \%$ (18 of 77 tumors). ${ }^{19}$ Other studies only evaluating collision tumors of a cutaneous malignancy and a seborrheic keratosis noted BCC-seborrheic keratosis MUSK IN A NEST to range from $14 \%$ (6 of 43 tumors) ${ }^{34}$ to $80 \%$ (43 of 54 tumors) ${ }^{35}$ the median was $26 \%$ (5 of 19 tumors). ${ }^{33}$

\section{Melanocytic and Pigmented Tumors}

BCC has been observed associated with lentigo and nevus. A retrospective study of 69 collision tumors demonstrated 1 BCC-associated lentigo and attributed the finding to represent a simple chance occurrence. ${ }^{31}$ Another retrospective study, using dermoscopy, noted 1 solar lentigo in 35 cutaneous skin lesions with a BCC component. ${ }^{19}$

A study of pigmented reticular structures in $\mathrm{BCC}$ and collision tumors noted $12 \mathrm{BCC}$. A solar lentigo was associated with six of the BCC. In addition, hyperpigmentation of the basal layer of the epidermis was observed in three of the BCC. $^{36}$

MUSK IN A NEST consisting of BCC and nevus range in incidence from $17 \%$ (4 of 24 tumors) ${ }^{32}$ to $20 \%$ (14 of
69 tumors $)^{31}$ in retrospective studies of cutaneous collision tumors. When nevi were evaluated, the frequency of an associated BCC ranged from less than $0.05 \%$ (Dr Stegmaier observed only 1 from a sampling of greater than 2000 nevi) ${ }^{37}$ to $0.25 \%$ (Dr. Meltzer observed 2 from a group of 800 nevi). ${ }^{37}$ And when BCC was studied, an associated nevus was noted in $0.2 \%$ (1 of $500 \mathrm{BCC}){ }^{37}$

Various subtypes of $\mathrm{BCC}$ were observed: fibroepithelioma of Pinkus, ${ }^{38}$ infiltrating, ${ }^{39}$ nodular, ${ }^{40}$ and pigmented. ${ }^{41}$ Also various types of nevi were noted including balloon cell nevus, ${ }^{42}$ blue nevus (one of which also had a speckled lentiginous nevus), ${ }^{43,44}$ combined nevus, ${ }^{38}$ compound nevus, ${ }^{30,32}$ intradermal nevus, ${ }^{32,37,46}$ and junctional nevus. ${ }^{32,41}$ Some of the BCC-associated MUSK IN A NEST with nevi were trineoplastic cutaneous tumors with three skin neoplasms: BCC, compound nevus and seborrheic keratosis, ${ }^{45} \mathrm{BCC}$, intradermal nevus and melanoma in situ ${ }^{46}$ and BCC, intradermal nevus and seborrheic keratosis. ${ }^{32}$

\section{Neural Tumors}

BCC-associated neurofibroma were observed in 6\% (4 of 69 ) of collision tumors. The investigators commented that 


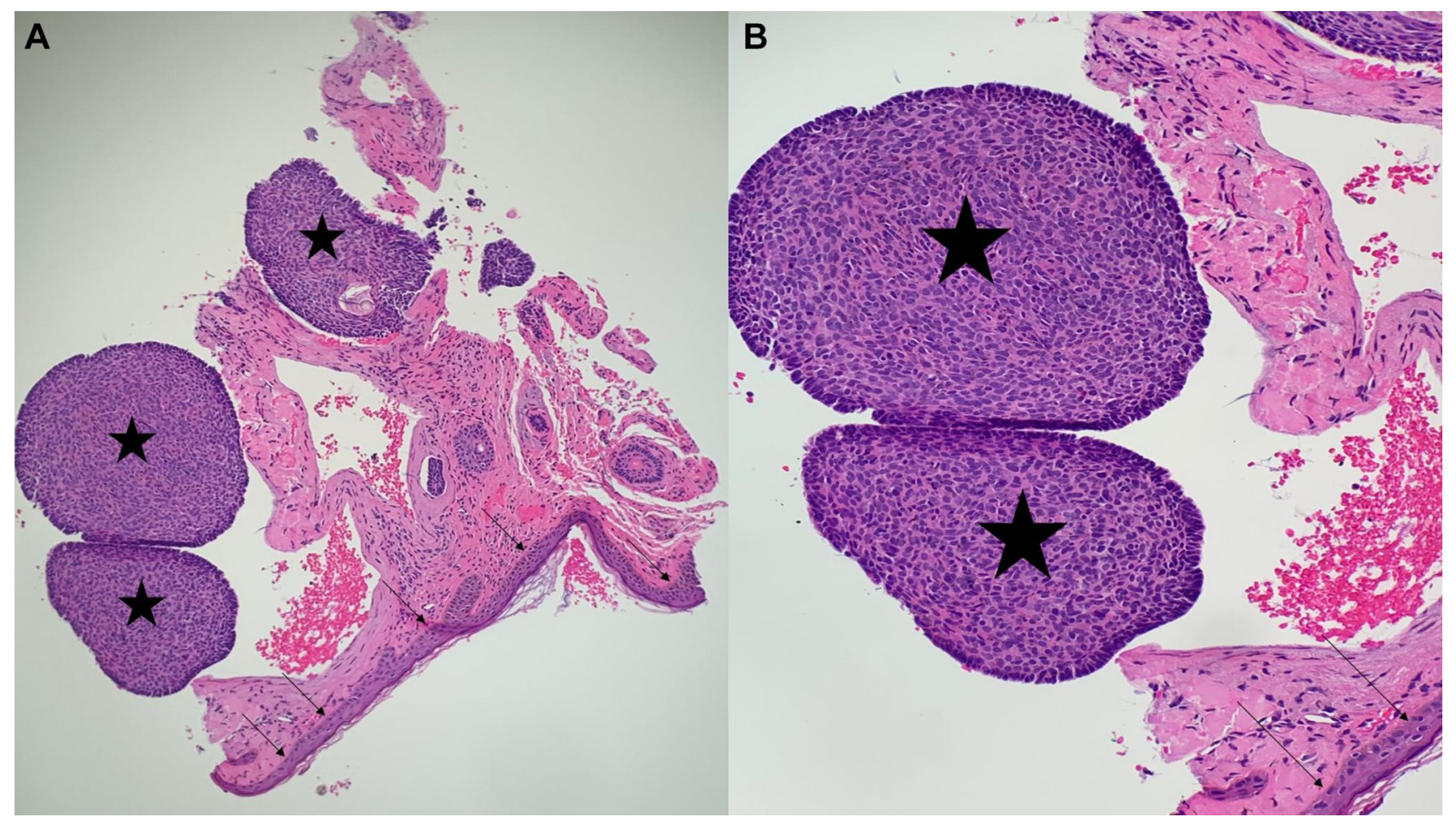

Figure 3 Microscopic examination of basal cell carcinoma and epidermal inclusion cyst-associated multiple skin neoplasms at one site (MUSK IN A NEST). Low magnification view (A) and higher magnification view (B) of another section of the hematoxylin and eosin stained specimen also only shows dermal tissue; the overlying epidermis is not visualized. The benign and malignant neoplasms in the dermis show a clonalium collision tumor consisting of a portion of the keratin-containing cyst (straight black arrows) adjacent to nodular aggregates of basaloid tumor cells (black stars). The pigment observed clinically is noted in the aggregates of basal cell carcinoma and along the cyst wall epithelium as basilar hyperpigmentation. The residual tumor was excised using the Mohs micrographic surgical technique (hematoxylin and eosin: $\mathbf{A}, x 4$; B, $x 10$ ).

mast cells may be present in either BCC or neurofibromas; in addition, the mast cells may not only be activated but also involved with the surrounding stromal elements. They speculated that BCC develops secondary to induction of the stromal pleuripotential cells by the neurofibromasassociated mast cells. ${ }^{31}$

\section{Vascular and Lymphatic Tumors}

Benign vascular lesions have been observed as a MUSK IN A NEST with a BCC. These include angiomas, lymphangioma, and a port wine stain. In a multicenter retrospective dermoscopy study of collision skin lesions, five lesions had a BCC with an angioma. ${ }^{19} \mathrm{~A} \mathrm{BCC}$-associated lymphangioma was observed in an 85-year-old man with a nodular lesion on his abdomen. ${ }^{47}$ In another case report, a nodular BCC developed on the margin of a port-wine stain on the left cheek of an 87-year-old man. ${ }^{48}$

\section{BCC-Associated MUSK IN A NEST and Malignant Tumors \\ Actinic Keratosis}

MUSK IN A NEST consisting of BCC and actinic keratoses have been described in retrospective dermoscopy studies. Investigators observed 1 actinic keratosis associated with a BCC in a study of 412 BCC that demonstrated 12 BCC-associated collision tumors. ${ }^{36}$ Other researchers noted 2 actinic keratoses amongst 35 collision skin lesions with a BCC component. ${ }^{19}$

\section{Keratoacanthoma and Squamous Cell Carcinomas}

The first observation of keratoacanthoma with BCC was described in 1968; a 54-year-old man presented with a growth on his right upper eyelid. ${ }^{54}$ In 1979, the second patient with BCC-associated keratoacanthoma was reported; the tumor appeared as a rapidly expanding lesion on the nose of a 44-year-old woman and was treated with radiotherapy since excision was refused. ${ }^{55} \mathrm{~A}$ third individual, a 61-year-old man, presented with a centrally umbilicated, rapidly growing, tumor on his nose that showed tumor nodules that had both keratoacanthoma keratinocytes that transitioned into anaplastic BCC basaloid cells. ${ }^{56}$ More recently, a dermoscopy study of cutaneous collision lesions demonstrated a BCC associated with a keratoacanthoma. ${ }^{19}$

Basosquamous cell carcinoma, also referred to as metatypical BCC, was first described in 1910; it is a variant of 
BCC and not a collision tumor. ${ }^{86}$ However, MUSK IN A NEST consisting of BCC and squamous cell carcinoma in situ or squamous cell carcinoma have been described. Some of these tumors have unusual features. ${ }^{73-75}$

A 71-year-old woman had a biopsy-confirmed squamous cell carcinoma in situ on her left palm; evaluation of the tumor debulking during Mohs micrographic surgery demonstrated not only the squamous cell carcinoma in situ in the epidermis but also BCC in the dermis. ${ }^{73}$ A 93-yearold woman developed a mass on her right lower eyelid; an excisional biopsy showed a tumor, arising from the epidermis, composed of adjoining BCC and signet-ring squamous cell carcinoma. ${ }^{74}$ And, a 60 -year-old man presented with a $15 \times 15$ centimeter fungating left should mass that was a MUSK IN A NEST consisting of adenoid BCC and squamous cell carcinoma; he also had metastatic adenoid BCC to his left axillary lymph node and subsequently to his right lung. ${ }^{75}$

\section{Atypical Fibroxanthoma}

BCC-associated MUSK IN A NEST and an atypical fibroxanthoma is rare. ${ }^{50-52}$ The first individual, reported in 2010, was an 85-year-old woman with a lesion of 3 -years duration on her nose; a black and violaceous hemorrhagic nodule was present in the center of an asymptomatic erythematous plaque. ${ }^{50,51}$ The second patient, described in 2015, was a 64-year-old man with a pink pearly plaque-with a hyperpigmented focus inferiorly-on his right temple. ${ }^{52}$ The woman's tumors were adjacent, yet well delimited; ${ }^{50}$ however, the man's neoplasms were not only adjacent but also intermixed. ${ }^{52}$

\section{Chronic Lymphocytic Leukemia}

Chronic lymphocytic leukemia, a clonal proliferation of mature B lymphocytes, typically presents after the age of 50 years. Occasionally, a dense infiltrate of leukemia lymphocytes will be observed adjacent to the tumor in a biopsy or excision specimen of BCC. Indeed, the diagnosis of unsuspected chronic lymphocytic leukemia has occasionally been established by this observation. ${ }^{53}$

\section{Melanoma}

The incidence of BCC-associated MUSK IN A NEST and melanoma is rare. A retrospective study observed the incidence of collision tumors of melanoma and BCC to be $0.014 \%$ (1.4 per 10,000). Specifically, only 11 melanoma-BCC collision tumors were observed among a series of 78,000 primary cutaneous carcinomas. ${ }^{58}$
The first patient with a collision tumor consisting of a BCC (metatypical) and malignant melanoma was presented at the 21st Annual Meeting of the American Society of Dermatopathology in Chicago-which took place on November 29-30, 1983-by Drs. Kao, Sulica, and Graham; ${ }^{59,60}$ however, the presentation was not included in the published abstracts. ${ }^{61}$ Within a year, Bhawan et al reported 2 men (ages 56 and 68 years old) with superficial spreading malignant melanoma in situ and pigmented BCC on their back in $1984 .{ }^{59}$ In 1987 , Coskey and Mehregan described the next case of BCCassociated MUSK IN A NEST and melanoma in a 50-year -old man with an amelanotic nodular melanoma and a pigmented BCC. ${ }^{60}$ The fourth patient with a BCCmelanoma collision tumor-lentigo maligna (melanoma in situ) and nodular melanoma on the right temple of an 83-year-old man-was described by Sina and Samorodin in $1989 .^{62}$

Several years later, in 1997, Burkhalter and White reported a 69-year-old man with a coexisting BCC and melanoma in situ on his right ear. ${ }^{63}$ In contrast to the earlier reports of BCC-associated MUSK IN A NEST and melanoma in which the BCC was only contiguous with the melanoma, the melanoma in situ in this patient not only extended peripheral to the BCC but also colonized the aggregates of BCC. Indeed, there was intermingling of the cells of the two different neoplasms; we refer to this presentation as clonalium colonization of the MUSK IN A NEST.

An extensive review of BCC-associated MUSK IN A NEST and melanoma was performed by Dinehart et al in 2018; they presented 4 patients and summarized the information on 45 previously reported individuals. They found that 16 patients had $\mathrm{BCC}$ that had been colonized by either lentigo maligna melanoma or melanoma in situ and another 16 patients had collision or combination of BCC and melanoma. The information provided in the reports of the remaining 17 patients was not sufficient to allow them to be classified. ${ }^{64}$

The prognosis and treatment of melanoma is based on the Breslow thickness depth of invasion. For patients with BCC-associated MUSK IN A NEST and melanoma, in whom the invasive melanoma is present peripheral to the BCC, the melanoma depth can be measured in a standard fashion. However, for patients in whom the melanoma has only colonized the aggregates of basaloid tumor cellswithout observed invasion into the dermis-it is uncertain whether the melanoma should be treated as an in situ or an invasive tumor. ${ }^{65}$ Several investigators favor considering 
the melanoma-colonized BCC as melanoma in situ; ${ }^{63,66}$ yet, other researchers advocate determining melanoma tumor thickness according to the depth of the melanocyte cells within the BCC. ${ }^{67}$

\section{Other Carcinomas}

Individual reports of patients with BCC-associated MUSK IN A NEST and carcinomas include Merkel cell carcinoma, ${ }^{68}$ sebaceous carcinoma, ${ }^{72}$ and verrucous carcinoma; ${ }^{12}$ the latter tumor was also associated with a syringocystadenoma papilliferum on the left occipital scalp of a 64-year-old man. ${ }^{12}$

Recently, a case report described a tumor on the forehead of an 87-year-old man which was believed by the investigators to represent a primary cutaneous biphasic sarcomatoid BCC with myoepithelial carcinoma differentiation. ${ }^{69}$ However, after evaluation of the histologic findings and molecular data, another researcher considered the neoplasm to be a collision tumor composed of a BCC and a myoepithelial carcinoma based on the identification of the EWSR1-PBX1 gene fusion in the myoepithelial component since EWSR1-PBX1 gene fusion has been documented in myoepithelial neoplasms of soft tissue. ${ }^{70}$

\section{Sarcomas}

Individual patients have also been described with MUSK IN A NEST composed of BCC and sarcoma. These include individuals with angiosarcoma, ${ }^{49}$ cutaneous leiomyosarcoma, ${ }^{57}$ and osteosarcoma. ${ }^{71}$

\section{Conclusion}

MUSK IN A NEST describes two or more cutaneous benign or malignant tumors occurring at the same cutaneous anatomic site. They can be classified based on the clonality of the neoplasms-clonalium (with collision, colonization, and combination subtypes) when the tumors are derived from different cell clones or clonalidem (with biphenotypic subtype) when the tumors originate from a single clone of cells and undergo clonal evolution. $\mathrm{BCC}$ can be a component of a MUSK IN A NEST. Dineoplastic cutaneous tumors, consisting of two skin neoplasms, are the most common BCC-associated MUSK IN A NEST. However, trineoplastic, tetraneoplastic, pentaneoplastic, and hexaneoplastic neoplasms (with three, four, five, or six skin neoplasms, respectively) have been described that have a BCC component. BCCassociated MUSK IN A NEST can occur with tumors that are either benign or malignant or both. It remains to be determined if BCC-associated MUSK IN A NEST is merely the coincidental juxtaposition of the tumors or whether the coexisting neoplasm directly or indirectly influences the development of the BCC at that location.

\section{Disclosure}

Philip R Cohen reports personal fees from ParaPRO, outside the submitted work. The authors report no other potential conflicts of interest for this work.

\section{References}

1. Lambertini M, Traniello Gradassi A, Misciali C, La Placa M. Apocrine papillary cystadenoma and basal cell carcinoma: an unusual collision tumor. G Ital Dermatol Venereol. 2017;152:682-684.

2. Shams PN, Oliver JM. A case of cutaneous collision tumour: the importance of photographic documentation and large incisional biopsy. Eye (Lond). 2006;20:1324-1325. doi:10.1038/sj.eye.6702192

3. Jayaprakasam A, Rene C. A benign or malignant eyelid lump-can you tell? An unusual collision tumour highlighting the difficulty differentiating a hidrocystoma from a basal cell carcinoma. $B M J$ Case Rep. 2012;2012:pii: bcr1220115307. doi:10.1136/ bcr.12.2011.5307

4. Rosenblum GA. Nevus sebaceus, syringocystadenoma papilliferum, and basal cell epithelioma. J Dermatol Surg Oncol. 1985;11 (10):1018-1020. doi:10.1111/j.1524-4725.1985.tb01388.x

5. Stavrianeas NG, Katoulis AC, Stratigeas NP, Karagianni IN, Patertou-Stavrianea M, Varelzidis AG. Development of multiple tumors in a sebaceous nevus of Jadassohn. Dermatology. 1997;195:155-158. doi:10.1159/000245721

6. Yoon DH, Jang IG, Kim TY, Kim HO, Kim CW. Syringocystadenoma papilliferum, basal cell carcinoma and trichilemmoma arising from nevus sebaceus of Jadassohn. Acta Derm Venereol. 1997;77:242-243.

7. Lillis PJ, Ceilley RI. Multiple tumors arising in nevus sebaceus. Cutis. 1979;23:310-314.

8. Namiki T, Miura K, Ueno M, Arima Y, Nishizawa A, Yokozeki H. Four different tumors arising in a nevus sebaceous. Case Rep Dermatol. 2016;8(1):75-79. doi:10.1159/000445822

9. Wang Y, Bu W-B, Chen H, et al. Basal cell carcinoma, syringocystadenoma papilliferum, trichilemmoma, and sebaceoma arising within a nevus sebaceus associated with pigmented nevi. Dermatol Surg. 2011;37(12):1806-1810. doi:10.1111/j.1524-4725.2011.02163. $\mathrm{x}$

10. Miller CJ, Ioffreda MD, Billingsley EM. Sebaceous carcinoma, basal cell carcinoma, trichoadenoma, trichoblastoma, and syringocystadenoma papilliferum arising within a nevus sebaceus. Dermatol Surg. 2004;30:1546-1549.

11. Nazzaro G, Vaira F, Pesapane F, Coggi A, Gianotti R. Tricholemmoma, sebaceoma, syringocystadenoma papilliferum, basal cell carcinoma, trichilemmal cyst arising within a nevus sebaceous. G Ital Dermatol Venereol. 2015;150:484-486.

12. Long T, Bonomo B, Shearer S, Welton W, Massullo R, Gibbons G. Is syringocystadenoma papilliferum incidental in this verrucous carcinoma? Case Rep Pathol. 2019;2019:1783758.

13. Spitz DF, Stadecker MJ, Grande DJ. Subclinical syringoma coexisting with basal cell carcinoma. $J$ Dermatol Surg Oncol. 1987;13:793-795. doi:10.1111/j.1524-4725.1987.tb00549.x

14. Shapiro H. Association of pilomatrixoma (calcifying epithelioma) and basal cell carcinoma: a case report. J Pathol Bacteriol. 1968;95:558-560. doi:10.1002/path.1700950233

15. Al Kaplan M, Kattampallil J, Rosendahl C. Trichilemmoma in continuity with pigmented basal cell carcinoma; with dermoscopy and dermatopathology. Dermatol Pract Concept. 2015;5:57-59. 
16. Wallace ML, Smoller BR. Trichoepithelioma with an adjacent basal cell carcinoma, transformation or collision? J Am Acad Dermatol. 1997;37:343-345. doi:10.1016/S0190-9622(97)80388-X

17. Sangwaiya A, Sharma J, Sharma S, Munghate A, Samal S, Sen R. Multiple familial trichoepithelioma with an adjacent basal cell carcinoma, transformation or collision - a case report and review of the literature. Indian J Dermatol. 2015;60:280-283. doi:10.4103/00195154.156380

18. Boran C, Parlak AH, Erkol H. Collision tumour of trichofolliculoma and basal cell carcinoma. Australas J Dermatol. 2007;48:127-129. doi:10.1111/j.1440-0960.2007.00352.x

19. Blum A, Siggs G, Marghoob AA, et al. Collision skin lesions-results of a multicenter study of the International Dermoscopy Society (IDS). Dermatol Pract Concept. 2017;7:51-62. doi:10.5826/ dpc.0704a12

20. Caron GA, Clink HM. Clinical association of basal cell carcinoma with histiocytoma. Arch Dermatol. 1964;90:271-273. doi:10.1001/ archderm.1964.01600030021004

21. Goette DK, Helwig EB. Basal cell carcinomas and basal cell carcinoma-like changes overlying dermatofibromas. Arch Dermatol. 1975;111:589-592. doi:10.1001/archderm.1975.01630170047005

22. Alinovi A, Benoldi D. A case in which the association between basal cell epithelioma and histiocytoma is demonstrated. Cutis. 1982;29:382-384.

23. Hafner C, Klein A, Landthaler M, Vogt T. Clonality of basal cell carcinoma arising in an epidermal nevus. New insights provided by molecular analysis. Dermatology. 2009;218:278-281. doi:10.1159/ 000189209

24. Sarkany I. Porokeratosis mibelli with basal cell epithelioma. Proc R Soc Med. 1973;66:435-436.

25. Glickman FS. Porokeratosis associated with basal cell carcinoma. Cutis. 1982;29:446-449.

26. Abudu B, Cohen PR. Pigmented basal cell carcinoma masquerading as a melanoma. Cureus. 2019;11:e4369.

27. Sibley K. Seborrhoeic verrucae and multiple basal-celled epitheliomata. Proc R Soc Med. 1932;25:670.

28. Sibley K. Seborrhoeic verrucae and multiple basal-celled epitheliomata. Proc R Soc Med. 1932;25:926.

29. Mikhail GR, Mehregan AH. Basal cell carcinoma in seborrheic keratosis. J Am Acad Dermatol. 1982;6:500-506. doi:10.1016/ S0190-9622(82)70042-8

30. Zaballos P, Llambrich A, Puig S, Malvehy J. Dermoscopy is useful for the recognition of benign-malignant compound tumours. Br J Dermatol. 2005;153:653-656. doi:10.1111/j.1365-2133.2005.06717.x

31. Boyd AS, Rapini RP. Cutaneous collision tumors. An analysis of 69 cases and review of the literature. Am J Dermatopathol. 1994;16 (3):253-257. doi:10.1097/00000372-199406000-00005

32. Moscarella E, Rabinovitz H, Oliviero MC, et al. The role of reflectance confocal microscopy as an aid in the diagnosis of collision tumors. Dermatology. 2013;227(2):109-117. doi:10.1159/000351771

33. Kwittken J. Malignant changes in seborrheic keratoses. Mt Sinai J Med. 1974;41:792-801.

34. Vun Y, De'Ambrosis B, Spelman L, et al. Seborrheic keratosis and malignancy: collision tumour or malignant transformation? Australas J Dermatol. 2006;47:106-108. doi:10.1111/j.1440-0960.2006.00242.x

35. Cascajo CD, Reichel M, Sanchez JL. Malignant neoplasms associated with seborrheic keratoses. An analysis of 54 cases. Am $J$ Dermatopathol. 1996;18(3):278-282. doi:10.1097/00000372199606000-00007

36. Gulia A, Altamura D, De Trane S, Micantonio T, Fargnoli MC, Peris K. Pigmented reticular structures in basal cell carcinoma and collision tumours. Br J Dermatol. 2010;162(2):442-444. doi:10.1111/ j.1365-2133.2009.09460.x

37. Sigal C, Saunders TS. Basal cell carcinoma and nevus pigmentosus. Their simultaneous occurrence. Arch Dermatol. 1967;96:520-523. doi:10.1001/archderm.1967.01610050042004
38. Sunassee A, Kerkvliet AM, Jassim AD. Combined melanocytic nevus, superficial congenital and deep penetrating types with fibroepithelioma of Pinkus, collision tumor-a case report. $S \mathrm{D} \mathrm{Med}$. 2017;70:363-365

39. Taira JW, Flaming JA, Weigand DA. Basal cell carcinoma and melanocytic nevus in the same lesion. Cutis. 1992;49:40-42.

40. Ansai S, Ogita A, Matsuda H, Saeki H, Tanaka M. Collision of basal cell carcinoma and melanocytic nevus with unique dermoscopic findings. $J$ Dermatol. 2016;43(5):584-585. doi:10.1111/1346-8138.13242

41. Bernardini MD, Moscarella E, Borsari S, et al. Collision tumors: a diagnostic challenge. J Am Acad Dermatol. 2016;75(6):e215e217. doi:10.1016/j.jaad.2016.03.021

42. Jain M, Carrera C, Marghoob AA. Basal cell carcinoma and balloon cell nevus collision mimicking a melanoma on reflectance confocal microscopy. JAAD Case Rep. 2020;6(4):339-340. doi:10.1016/j. jdcr.2020.02.021

43. Betti R, Inselvini E, Crosti C. Blue nevi and basal cell carcinoma within a speckled lentiginous nevus. $J$ Am Acad Dermatol. 1999;41:1039-1041. doi:10.1016/S0190-9622(99)70272-0

44. Litak J, Behroozan D, Binder S. Co-existing basal cell carcinoma and blue nevus in an African-American woman. J Cutan Pathol. 2009;36:1114-1116. doi:10.1111/j.1600-0560.2008.01245.x

45. de Giorgi V, Massi D, Sestini S, Alfaioli B, Carelli G, Carli P. Cutaneous collision tumour (melanocytic naevus, basal cell carcinoma, seborrhoeic keratosis): a clinical, dermoscopic and pathological case report. $\mathrm{Br} J$ Dermatol. 2005;152:787-790. doi:10.1111/ j.1365-2133.2005.06448.x

46. Scalvenzi M, Costa C, Palmisano F, Fabbrocini G, Siano M, Staibano S. Clinical, dermoscopic and histological features of a combined tumor composed of melanoma in situ, a basal cell carcinoma and an intradermal naevus. Dermatol Rep. 2012;4:e11. doi:10.4081/dr.2012.e11

47. Blum A, Maltagliati-Holzner P, Deinlein T, Hofmann-Wellenhof R. Collision tumors in dermoscopy: a new challenge. Hautarzt. 2018;69:776-779. doi:10.1007/s00105-018-4172-z

48. Silapunt S, Goldberg LH, Thurber M, Friedman PM. Basal cell carcinoma arising in a port-wine stain. Dermatol Surg. 2004;30:1241-1245.

49. Rongioletti F, Albertini AF, Fausti V, Cinotti E, Parodi A, Fraitag S. Pseudolymphomatous cutaneous angiosarcoma: a report of 2 new casers arising in an unusual setting. $J$ Cutan Pathol. 2013;40:848-854. doi:10.1111/cup.12166

50. Alves R, Ocana J, Vale E, Correia S, Viana I, Bordalo O. Basal cell carcinoma and atypical fibroxanthoma: an unusual collision tumor. J Am Acad Dermatol. 2010;63:e74-e76. doi:10.1016/j. jaad.2009.11.685

51. Alves R, Ocana J, Vale E, Viana I. Commentary to the article "A rare collision in dermatopathology: basal cell carcinoma and atypical fibroxanthoma". Am J Dermatopathol. 2018;40:75-76. doi:10.1097/ DAD.0000000000000835

52. Speiser JJ, Aggarwal S, Wold L, Tung R, Hutchens KA. A rare collision in dermatopathology: basal cell carcinoma and atypical fibroxanthoma. Am J Dermatopathol. 2015;37(12):950-953. doi:10.1097/DAD.0000000000000208

53. Mays SR, Cohen PR. Emerging dermatologic issues in the oncology patient. Semin Cutan Med Surg. 2006;25:179-189. doi:10.1016/j. sder.2006.08.007

54. Einaugler RB, Henkind P, De Oliveira LF, Bart RS. Keratoacanthoma with basal cell carcinoma. Am J Ophthalmol. 1968;65:922-925. doi:10.1016/0002-9394(68)92223-X

55. Butcher RB 2nd. Malignant potential of keratoacanthoma. Laryngoscope. 1979;89:1092-1098. doi:10.1288/00005537197907000-00008

56. Bryant J. Basal cell carcinoma associated with keratoacanthoma. J Dermatol Surg Oncol. 1985;11:1230-1231. doi:10.1111/j.15244725.1985.tb03104.x 
57. Gulseren D, Noland MM, Gru AA. Coexistence of a basal cell carcinoma and leiomyosarcoma: an unusual collision tumor. Am J Dermatopathol. 2019;41:956-958. doi:10.1097/DAD.0000000000001383

58. Pierard GE, Fazaa B, Henry F, Kamoun MR, Pierard-Franchimont C. Collision of primary malignant neoplasms on the skin: the connection between malignant melanoma and basal cell carcinoma. Dermatology. 1997;194(4):378-379. doi:10.1159/000246154

59. Bhawan J, Mehregan AH, Jung-Legg Y, Gellis SE. Pigmented basal cell carcinoma and superficial spreading malignant melanoma: an unusual combination. $J$ Cutan Pathol. 1984;11(6):471-475. doi:10.1111/j.1600-0560.1984.tb00405.x

60. Coskey RJ, Mehregan AH. The association of basal cell carcinomas with other tumors. J Dermatol Surg Oncol. 1987;13:553-555. doi:10.1111/j.1524-4725.1987.tb00941.x

61. American Society of Dermatopathology abstracts. Annual meeting, Nov 29-30, 1983. Arch Dermatol. 1984;120:1079-1087. doi:10.1001/archderm.1984.01650440109033

62. Sina B, Samorodin C. Basal cell carcinoma surrounded by lentigo maligna. Cutis. 1989;44:81-82.

63. Burkhalter A, White WL. Malignant melanoma in situ colonizing basal cell carcinoma. A simulator of invasive melanoma. Am J Dermatopathol. 1997;19:303-307. doi:10.1097/00000372-199706000-00019

64. Dinehart M, Abate MS, Jennings T, Kaley JR, Shalin SC. Colliding, colonizing or combining? Four cases illustrating the unique challenges presented by melanoma arising in conjunction with basal cell carcinoma. J Cutan Pathol. 2018;45:443-452. doi:10.1111/cup.13137

65. Ryan MP, Bennett DD, Goodwin BP, Kelly BC. Basomelanocytic neoplasms: a report of two similar tumors with divergent treatments. Am J Dermatopathol. 2020;42:530-532. doi:10.1097/DAD.00 00000000001555

66. Kuonen F, Aschwanden J, Dimaio DJ, et al. Colonisation of basal cell carcinoma by lentigo maligna: a case report, review of the literature, and series follow-up. Eur J Dermatol. 2016;26:465-469. doi:10.1684/ ejd.2016.2820

67. Braun-Falco M. Combined malignant melanoma and basal cell carcinoma tumor of the intermingled type. $J$ Cutan Pathol. 2007;34:731-735. doi:10.1111/j.1600-0560.2006.00703.x

68. Simstein NL, Sduggs NK. Merkel cell tumor: two cases. Int Surg. 1998;83:60-62.

69. Mestre-Alagarda C, Nieto G, Terradez L, Monteagudo C. Primary cutaneous biphasic sarcomatoid basal cell carcinoma with myoepithelial carcinoma differentiation: a new variant. J Cutan Pathol. 2019;46 (12):949-953. doi:10.1111/cup.13543

70. Tran TAN. "Primary cutaneous biphasic sarcomatoid basal cell carcinoma with myoepithelial carcinoma differentiation." Is it a new variant of sarcomatoid basal cell carcinoma or a collision tumor composed of a myoepithelial carcinoma and an incidental basal cell carcinoma? J Cutan Pathol. 2020. doi:10.1111/cup.13651

71. Llamas-Velasco M, Rutten A, Requena L, Mentzel T. Primary cutaneous osteosarcoma of the skin: a report of 2 cases with emphasis on the differential diagnoses. Am J Dermatopathol. 2013;35(6):e106e113. doi:10.1097/DAD.0b013e31827f0a6f
72. Levy J, Cagnano E, Benharroch D, Monos T, Lifshitz T. Collision sebaceous and basal cell carcinomas of the eyelid. Ann Diagn Pathol. 2006;10:157-159. doi:10.1016/j.anndiagpath.2005.07.018

73. Lam C, Fuller C, Flamm A, Billingsley EM. Collision tumor of basal and squamous cell carcinoma of the palm. J Clin Aesthet Dermatol. 2019;12(4):28-30.

74. Proia AD, Selim MA, Reutter JC, Michon JJ. Basal cell-signet-ring squamous cell carcinoma of the eyelid. Arch Pathol Lab Med. 2006;130:393-396.

75. Li R, Lee G, Huang M, El-Sherief A. Rare basal cell metastasis of a basal-squamous skin collision tumor to the lung and axillary lymph node. BMJ Case Rep. 2019;12(10):pii: e231487. doi:10.1136/bcr2019-231487

76. Hendricks K Biziura lobata (musk duck). Animal Diversity Web. Available from: https://animaldiversity.org/accounts/Biziura_lobata/. Accessed August 14, 2020.

77. Courtney J, Debus S. Breeding habits and conservation status of the musk lorikeet Glossopsitta concinna and little lorikeet G. pussilla in northern New South Wales. Aust Field Ornithol. 2006;23:109-124.

78. World Heritage Encyclopedia. IUPAC numerical multiplier. Article Id: WHEBN0002911939. Available from: www.gutenberg.us/articles/ IUPAC_numerical_multiplier. Accessed September 7, 2020.

79. Cornejo KM, Deng AC. Malignant melanoma within squamous cell carcinoma and basal cell carcinoma: is it a combined or collision tumor?-a case report and review of the literature. Am J Dermatopathol. 2013;35(2):226-234. doi:10.1097/DAD.0b013e3182545e27

80. Idriss MH, Elston DM. Secondary neoplasms associated with nevus sebaceus of Jadassohn: a study of 707 cases. J Am Acad Dermatol. 2014;70:332-337. doi:10.1016/j.jaad.2013.10.004

81. Ball EAM, Hussain M, Moss ALH. Squamous cell carcinoma and basal cell carcinoma arising in a naevus sebaceous of Jadassohn: case report and literature review. Clin Exp Dermatol. 2005;30:259-260. doi:10.1111/j.1365-2230.2005.01744.x

82. Satter EK, Metcalf J, Lountzis N, Elston DM. Tumors composed of malignant epithelial and melanocytic populations: a case series and review of the literature. J Cutan Pathol. 2009;36:211-219. doi:10.1111/j.1600-0560.2008.01000.x

83. Rosen LB, Williams WD, Benson J, Rywlin AM. A malignant neoplasm with features of both squamous cell carcinoma and malignant melanoma. Am J Dermatopathol. 1984;6:213-219.

84. Rodriguez J, Nonaka D, Kuhn E, Reichel M, Rosai J. Combined high-grade basal cell carcinoma and malignant melanoma of the skin ("malignant basomelanocytic tumor"): report of two cases and review of the literature. Am J Dermatopathol. 2005;27:314-318. doi:10.1097/01.dad.0000171600.17692.65

85. Basu P, Erickson CP, Calame A, Cohen PR. Nevus sebaceus with syringocystadenoma papilleferum, prurigo nodularis, apocrine cystadenoma, basaloid follicular proliferation and sebaceoma: case report and review of nevus sebaceus-associated conditions. Dermatol Online J. 2020;26:2.

86. Jones MS, Helm KF, Maloney ME. The immunohistochemical characteristics of the basosquamous cell carcinoma. Dermatol Surg. 1997;23(3):181-184. doi:10.1111/j.1524-4725.1997.tb00017.x
Clinical, Cosmetic and Investigational Dermatology is an international, peer-reviewed, open access, online journal that focuses on the latest clinical and experimental research in all aspects of skin disease and cosmetic interventions. This journal is indexed on CAS
The manuscript management system is completely online and includes a very quick and fair peer-review system, which is all easy to use. Visit http://www.dovepress.com/testimonials.php to read real quotes from published authors. 